

ISSN 2357-9854

\title{
(In) versões didáticas: \\ possibilidades poéticas para processos de formação docente
}

\author{
Rita Luciana Berti Bredariolli ${ }^{1}$ (Universidade Estadual Paulista — UNESP, São \\ Paulo/SP, Brasil)
}

\begin{abstract}
RESUMO - (In) versões didáticas: possibilidades poéticas para processos de formação docente - Conhecimentos sobre as imagens e pelas imagens resultam de um trabalho de relação, de um trabalho de montagem, pelo qual situamos, em ação relacional, indícios, textos, lacunas e outras imagens visíveis ou não. Trata-se de um trabalho de imaginação: "imiscuir-se" nas imagens, ativandoas em montagem a outras imagens ou textos, impulsionando um movimento relacional que "age sobre a nossa própria atividade de saber e de pensar". "Para saber, é preciso imaginar-se". Partindo dessas considerações, abordaremos nesse texto as imagens - visíveis e não-visíveis - e a imaginação como possibilidades de formação docente. Apresentaremos algumas das variações conceituais sobre imagem em sua relação com o saber, enfatizando a revisão epistemológica que revitaliza e reposiciona o valor e a função das imagens e da imaginação no processo cognitivo e, sobretudo, como possibilidades de um processo de formação docente voltado ao ensino das artes, delineado pela assunção da importância, necessidade e inseparabilidade do exercício da inteligibilidade e sensibilidade.
\end{abstract}

\section{PALAVRAS-CHAVE}

Imagens. Imaginação. Formação docente

RESUMEN - (En) versiones didácticas: posibilidades poéticas para los procesos de formación docente - Los conocimientos acerca de las imágenes y a través de las imágenes son el resultado de una tarea de relación, de una tarea de montaje mediante el cual situamos en la acción relacional indicios, textos, lagunas, otras imágenes, visibles o no. Se trata de una tarea de imaginación: "inmiscuirse" en las imágenes activándolas en un montaje con otras imágenes o textos, impulsando un movimiento relacional que "actúa sobre nuestra propia manera de saber y de pensar". "Para saber hay que imaginarse". Partiendo de estas consideraciones, abordaremos en este texto las imágenes visibles e invisibles - y la imaginación como posibilidades en la formación docente. Presentaremos algunas de las variaciones conceptuales sobre la imagen en relación con el saber, haciendo énfasis en la revisión epistemológica que revitaliza y redefine el valor y la función de las imágenes y de la imaginación en el proceso cognitivo y principalmente, como posibilidades de un proceso de formación docente volcado en la enseñanza de las artes, delimitado por la asunción de la importancia, la necesidad y la inseparabilidad del ejercicio da inteligibilidad y sensibilidad.

PALABRAS CLAVE

Imágenes. Imaginación. Formación docente

1 Foi bolsista CAPES do Programa de Estágio Pós-Doutoral no Exterior (2015).

BREDARIOLLI, Rita Luciana Berti. (In) versões didáticas: possibilidades poéticas para processos de

formação docente

Revista GEARTE, Porto Alegre, v. 3, n. 1, p. 96-109, jan./abr. 2016.

Disponível em: http://seer.ufrgs.br/gearte 


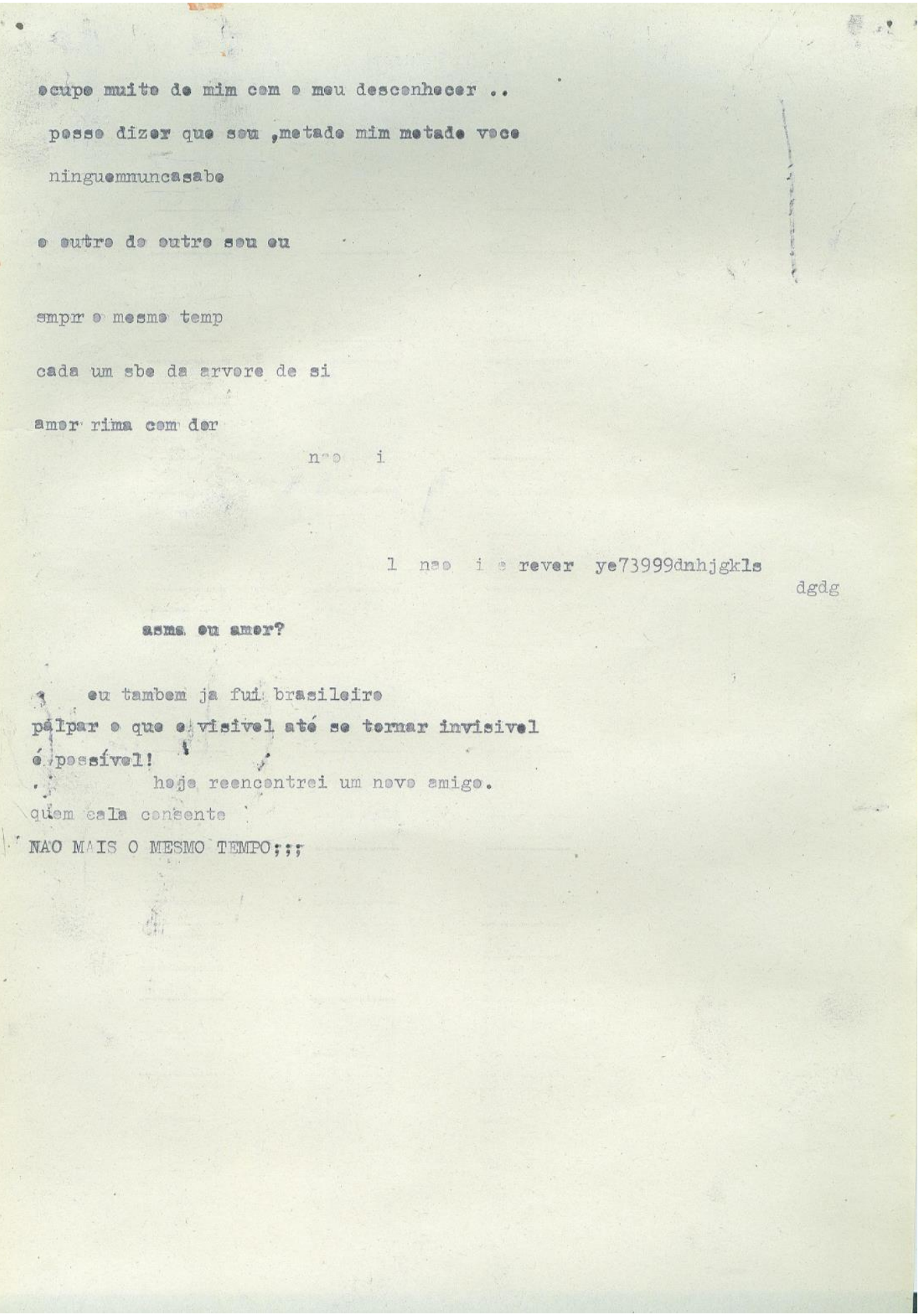

Uma imagem sem imaginação é pura e simplesmente uma imagem que ainda não nos dedicamos a trabalhar. Pois a imaginação é trabalho, esse tempo de trabalho das imagens agindo incessantemente uma sobre as outras por colisões ou fusões, por rupturas ou metamorfoses...Sendo que tudo isso age sobre nossa própria atividade de saber e de pensar. Para saber, portanto, é 
realmente preciso imaginar-se: a mesa de trabalho especulativa é inseparável de uma mesa de montagem imaginativa² ${ }^{2}$

No texto Aportes de la Imagen en la Formación Docente: abordajes conceptuales y pedagógicos (DUSSEL et. al., 2010) são expostos dois argumentos comumente usados para justificar a presença das imagens em processos educacionais. O primeiro, designado "argumento cultural", seria derivado do reconhecimento de uma predominação da imagem em contextos contemporâneos, gerada e mantida pelo excesso e velocidade de sua produção, motivo de impedimento de um tempo de recepção propício ao estabelecimento de uma "leitura" adequada, pois reflexiva e crítica, destas imagens. Este argumento encontraria respaldo, por exemplo, em textos como "Sociedade do Espetáculo" de Guy Debord, publicado em 1967. O segundo argumento, relacionado a esse, seria o "argumento didático", que fundamenta o entendimento das imagens como meios de acesso a outros conteúdos. Esse dois argumentos, de acordo com os autores do texto citado no início deste parágrafo, embora sejam fundamentais para a abertura ao pensamento sobre as relações entre imagens e educação, seriam ambos limitadores, pois posicionariam as imagens em um lugar de subordinação a um "conhecimento verdadeiramente valioso", a elas externo.

Nesse sentido, se manteria conservado o entendimento das imagens como ilustrações, ou como "coisas", cujo sentido somente seria encontrado em projeções discursivas exteriores quer pela via da análise formalista, quer pela "crítica ideológica ou política". Nesse caso, as imagens sofreriam uma espécie de "escolarização", no pior sentido do verbo "escolarizar", limitando sua "leitura" sob a força de explicações predeterminadas (DUSSEL et. al., 2010, p. 4). Tais elaborações expõem um modo convencional de relacionamento com a imagem, ainda persistente em nossos universos escolares - sejam universos de formação básica ou superior -, locais de submissão da imagem à primazia do texto e ao conservadorismo epistemológico, mantendo em persistência a "certeza inelutável" de que os processos de formação

2 DIDI-HUBERMAN, Georges. Imagens Apesar de Tudo. KKYM. Lisboa, 2012, p. 154. 
acontecem somente pelo desvelamento, pela superexposição e esgotamento dos temas, geralmente, encerrados em explicações verbais conclusivas.

"Para saber há que imaginar-se". Essa afirmação de Georges Didi-Huberman (2012), retirada de um contexto distante das preocupações educacionais, mas nem por isso menos apropriada às nossas reflexões, nos conduz à mobilização dessa forma convencional de compreensão ou estabelecimento das relações entre imagens e saber. Diante de uma imagem, estaríamos diante de uma porta aberta. Aparentemente nada nos seria ocultado, mas, ao mesmo tempo, a luz que dessa abertura emerge e nos atrai, também "quase nos cega, nos controla" (DIDIHUBERMAN, 2008, p. 31).

A leitura dessa metáfora, exposta por Didi-Huberman, nos remete ao encontro de cognoscibilidade com as imagens como um acontecimento engendrado nesse duplo movimento, tensionado, entre visibilidade e invisibilidade; de abertura "a nós" e fechamento "sobre nós", regulado em interação ao movimento pulsante de nosso corpo, suscitando algo que poderia ser nomeado, segundo o autor, como uma "experiência interior" (DIDI-HUBERMAN, 2007, p. 25), em uma alusão ao texto de Georges Bataille, L'expérience intérieure. Uma "experiência" que escapa ao limite de definição, segundo Bataille, pois ela é o próprio estado de questão, ela "existe no coração do possível"3. Bataille, em sua elaboração sobre o conceito de "experiência interior", evidencia a necessidade de reconsiderarmos o envolvimento corporal, sensível - o "transe" - aos "domínios do saber", geralmente entendidos sob a regência de uma intelecção apartada do sensível, requerido por Bataille.

Ao considerar a inseparabilidade das faculdades sensível e inteligível em processos cognitivos, Bataille retoma a potência do vínculo fundante e indissolúvel entre o sujeito e o mundo. Para Bataille, '“si-mesmo' não é o sujeito se isolando do

3 L'expérience est la mise en question (à l'epreuve), dans la fiève et l'angoisse de ce qu'un homme sait du fait d'être [...] Et comme "l'expérience intérieure" existe au coeur du possible, il n'est pas de définition que je puissé donner qui ne se lie à la necessite, dont j'ai parle, de tout mettre en question sans mesure ( BATAILLE, 1973, p. 15; 427). 
mundo, mas um lugar de comunicação, de fusão do sujeito e do objeto"4. Por essa inerência, afetariam-se, mutuamente, tornando-se ambos responsáveis pelo acontecimento dessa relação: o saber. As "condições da observação mudam a natureza do fenômeno observado"5, e, em continuidade a esta afirmação de Bataille, diríamos que, em ação recíproca, também a natureza do observador seria alterada (DIDI-HUBERMAN, 2005).

Esse mesmo texto de Bataille foi evocado também por Apolline Torregrosa Laborie, ao expor em crítica, o binarismo sujeito-objeto (LABORIE, 2012, p. 34), fundamento consolidado por certa forma de entendimento e prática do saber, ainda predominante em âmbitos educacionais. Para Laborie, o ensino da arte seria o lugar potencial do acontecimento e da evidência de processos cognitivos fundados sob o reconhecimento da necessária reintegração dos binarismos determinados por certa convenção epistemológica. Durante a experimentação artística, reflexão e prática, inteligibilidade e sensibilidade, sujeito e objeto seriam articulados em organicidade. $O$ ensino da arte seria, portanto, o espaço da "experiência interior". Por ela, segundo Laborie, reabriríamos "as portas do possível”, reintegrando ao espaço formativo os "múltiplos possíveis, as vivências [...] reunindo a razão e o sensível através daquilo que se vive, pelas reminiscências, a presença interior que nos entrega seus segredos do coração" (LABORIE, 2012, p. 35) ${ }^{6}$.

Por sua vez, Didi-Huberman, ao evocar a "experiência interior", o fez em referência a outro lugar, que pode ser considerado como parte daquele da formação artística mencionado por Laborie. Didi-Huberman referia-se ao encontro entre sujeitos e imagens, ponto de eclosão de possibilidades no "exercício do ver e do saber", - e,

4 [...] "soi-même" ce n'est pas le sujet s'isolant du monde, mais um lieux de comunication, de fusion du sujet et de I'objet ( BATAILLE, 1973, p. 21).

5 [...] les conditions de l'observation changent la nature du phénoméné observé" ( BATAILLE, 1973, p. 428).

6 [...]Por la experiencia, reabrimos las puertas de lo posible, lo reintegramos en el espacio formativo, los múltiples posibles, vivencias, tendencias que han sido selados por una educación que dice, que impone lo que es. La experiencia interior, tal como la describe Georges Bataille, es una reapertura a lo incógnito, es el extremo de lo posible, reuniendo la razón y lo sensible a través de lo que se vive, por las reminiscencias, la presencia interior que nos entrega sus secretos del corazón (LABORIE, 2012, p. 35) 
diríamos, do "ler"7 -, decorrente, a princípio, "de uma preocupação epistemológica: não se separa a observação do observador” (DIDI-HUBERMAN, 2012, p. 201).

Do reconhecimento dessa inseparabilidade, depreende-se a "leitura" das imagens como um movimento incessante de criação e recriação, estabelecido em uma trama de tempos heterogêneos implicados em um "momento crítico", definido pelas inter-relações entre o visível e o invisível. Nesse sentido, a "leitura" de imagens é sempre uma "atualização", entendida aqui como a transformação de uma potencialidade em ato. Transformação provocada pelo encontro com outros vários atos, entre vários tempos distintos evocados por histórias e memórias, cujo entrelaçamento ao presente possibilita sua reinterpretação: os tempos da imagem, os tempos na imagem, os tempos experimentados por aquele que a contempla, o tempo mesmo da contemplação, para "ler o que nunca foi escrito". A "leitura" de uma imagem convoca esses muitos e vários tempos e é nesse encontro - ou nesse choque entre o Pretérito e o Agora (DIDI-HUBERMAN, 2005, p. 182) - que os sentidos se estabelecem. A "leitura" de uma imagem se dá na intersecção de repertórios em revivescências. Esse processo desencadeia a ativação de outras imagens e o exercício de situá-las em relação. Ativa, portanto, nossa imaginação e nossos sentidos, os quais, em reciprocidade, reavivam essa movimentação. Contemplar uma imagem ou, se dispor ao tempo de relacionamento com uma imagem, ao tempo de trabalho sobre a imagem, é "desejá-la". Desejo emergente da e na dedicação ao tempo de contemplação, lugar-tempo definido pela coalescência do sensível e inteligível.

As imagens são "algo entre o mundo dos signos e o mundo do corpo". Não devem ser limitadas a abstrações ou emblemas de uma ideia, tampouco reduzidas a projeções de nós mesmos, ao encerrarmos sua "leitura" pela imposição de predeterminações. As imagens são assumidas então como "pedaços do real". E isso

7 Ler no sentido atribuído por Walter Benjamin como leitura do mundo em articulação às "condições imanentes, fenomenológicas ou históricas da própria 'visibilidade' das coisas". Uma leitura livre do "modelo puramente linguístico, retórico ou argumentativo", definida pelas "relações íntimas e secretas", pelas “"correspondências"” e "'analogias"” (DIDI-HUBERMAN, 2013, p. 15). "A legibilidade benjaminiana deve ser compreendida como um momento essencial da imagem mesma - que ela não reduz, posto que dela procede - e, não como sua explicação [...]"(DIDI-HUBERMAN, 2005, p. 182). 
não significa que tomamos a imagem como o duplo desse real, como seu reflexo ou sua aparência. Noções que afirmam a condição da imagem como ilusão, como ludíbrio, e a nossa como de ludibriados, convenção crítica problematizada por Jacques Rancière (2010). A “crítica do espetáculo" e os "discursos do irrepresentável” nutriram, segundo Rancière, "uma desconfiança global em relação à capacidade política de toda e qualquer imagem". Ceticismo que seria "resultado de um excesso de fé", nascido da "crença desiludida numa linha reta entre percepção, afecção, compreensão e ação". Tal "esquema estratégico" - derivado de outra crença, a da separação entre aparência e verdade - deve ser objeto de crítica para que uma "nova confiança na capacidade política das imagens" possa se manifestar. As imagens, para Rancière, são elementos "dentro de um dispositivo que cria um certo sentido de realidade, um certo senso comum", o que pode ser definido como "uma comunidade de dados sensíveis", de "maneiras comuns de perceber, de ser afetado e de atribuir sentido". O problema, para o autor, não está na oposição entre realidade e suas aparências, mas sim na construção de "outras realidades, outras formas de senso comum, ou seja, outros dispositivos espaço-temporais, outras comunidades das palavras e das coisas, das formas e das significações", na construção de novas paisagens “do possível” (RANCIĖRE, 2010, p. 149-151).

A “imagem não é o duplo de uma coisa", afirma Rancière, ela é "um jogo complexo de relações entre o visível e o invisível, entre o visível e a palavra, entre o dito e o não dito". Também não deve ser tomada como "a simples reprodução do que surgiu em frente ao fotógrafo ou do cineasta". A imagem, para Rancière, é "sempre uma alteração que ocorre numa cadeia de imagens que, por seu turno, a altera também" (RANCIĖRE, 2010, p. 139).

A crítica de Rancière é construída sobre o que Jean Paul Sartre definiu como uma "ontologia ingênua da imagem", estabelecida pela "confusão" entre "identidade de essência e identidade de aparência". A "teoria pura e a priori" fez da imagem, "coisa" (SARTRE, 2011, p. 10-11), o que ela não é. A imagem para Sartre é "um certo tipo de consciência [...] um ato e não uma coisa. A imagem é consciência de alguma coisa" (SARTRE, 2011, p. 137). É "consciência" e não uma réplica falaciosa do real, uma "coisa menor" separada da "verdade" que representa. A crença na "imagem- 
ilusão", estabelecida nesta separação, segundo Rancière, reiteraria o seu oposto. Ao compreendermos a imagem como ilusão, como duplo de uma realidade, estaríamos a afirmá-la como a própria realidade. A crítica fundamentada pela ideia de "imagemilusão" é crente. Acaba por atribuir um poder dogmático à imagem, destituindo-a de sua própria topografia, de sua própria realidade como "consciência". Neste sentido, o observador é posicionado em uma condição passiva, subjugado por uma realidade mais que real por ser considerada sua própria ilusão. O observador é, então, segregado do processo de construção de sentidos, de constituição e reconstituição da própria imagem.

O relacionamento com imagens demanda o desdobramento, o "mais possível", de sua fenomenologia. Reiteradamente de sua fenomenologia, diferente de uma "percepção propriamente dita", mas, como afirmou Sartre, de "uma quase-observação do mundo" (SARTRE apud DIDI-HUBERMAN, 2012, p. 148), o que implica a consideração do vínculo estabelecido nesse encontro entre aquele que olha e aquilo que é olhado - o sujeito e o objeto, convencionalmente falando -; do entrecruzamento de tempos - e outras imagens - evocados por esse encontro; e dos processos inteligíveis e sensíveis em atuação constante e conjunta no tempo desse encontro.

Em oposição ao "platonismo trivial da imagem-ilusão", Didi-Huberman recorda a "posição aristotélica", experimental, de acordo com a qual a existência de um objeto é inseparável das "'grandezas sensíveis"'. Seria, então, nas '"formas sensíveis que os inteligíveis existem [...] por esse motivo [...] que o próprio exercício do intelecto deve ser acompanhado por uma imagem"' (DIDI-HUBERMAN, 2012, p. 146). Imagens são potências de cognição; são atos de cognoscibilidade eclodidos da indissociável e simultânea "montagem" dos "sensíveis" e "inteligíveis".

Conhecimentos sobre as imagens e pelas imagens resultam de um trabalho de montagem, pelo qual situamos, em relação, indícios, rastros, lacunas, outras imagens, visíveis ou não. Trata-se de um trabalho de imaginação: "imiscuir-se" nas imagens, ativando-as em montagem a outras imagens ou textos, engendrando "colisões ou fusões, por rupturas ou metamorfoses", impulsionando esse movimento relacional que "age sobre a nossa própria atividade de saber e de pensar" (DIDI-HUBERMAN, 2012, p. 154). "Para saber, é preciso imaginar-se". 


\section{[...] no hay imagen sin imaginación ${ }^{8}$}

Imaginação e fantasia não são o mesmo, afirmava Baudelaire. Também a imaginação "não é" - essencialmente - "a sensibilidade", escreveu o autor em "Novas Notas sobre Edgar Poe". Para Baudelaire, a imaginação é uma faculdade "quase divina", que "para além dos métodos filosóficos", apreende "as relações íntimas e quase secretas entre as coisas, as correspondências e as analogias" (BAUDELAIRE In LOURENÇO, 2006, p. 104). Posteriormente, em "A rainha das faculdades", Baudelaire definiria imaginação, esta "misteriosa faculdade", como análise e síntese. Para Baudelaire, a imaginação "ensinou ao homem o sentido moral da cor, do contorno, do som e do perfume". Foi responsável pela criação, "no começo do mundo", da "analogia" e da "metáfora". A imaginação seria capaz de decompor criações, mas também de rearranjá-las, segundo regras originadas nas profundezas da alma, criando "um mundo novo", a "sensação do novo". Para Baudelaire, a imaginação seria "a rainha do verdadeiro, e o possível é uma das províncias do verdadeiro". A imaginação estaria, nesse sentido, "aparentada com o infinito" (BAUDELAIRE In LOURENÇO, 2006, p. 158-159).

Em "O Governo da Imaginação", Baudelaire, fará referência à metáfora da natureza como dicionário. Para entendê-la, haveria que "imaginar as numerosas e habituais utilizações do dicionário". Nele, procuramos o sentido das palavras, sua origem, sua etimologia. Dele extraímos "todos os elementos que compõem uma frase e uma história; mas nunca ninguém considerou o dicionário como uma composição no sentido poético da palavra". Aqueles que "obedecem à imaginação procuram no seu dicionário os elementos que se harmonizam com a sua concepção", atribuindoIhes "uma fisionomia totalmente nova" ao articulá-los com "uma certa arte". Para Baudelaire, todo o "universo visível não é mais que um armazém de imagens e de

8 DIDI-HUBERMAN, Georges. Cuando las imágenes tocan lo real. Disponível em: $<$ http://www.macba.cat/uploads/20080408/Georges Didi Huberman Cuando las imagenes toca $\mathrm{n}$ lo real.pdf $>$. Acesso: 29 mar. 2016. 
sinais aos quais a imaginação irá atribuir um lugar e um valor relativo" (BAUDELAIRE In LOURENÇO, 2006, p. 161-162).

A imaginação se definiria como "dupla faculdade de observação e extrapolação" (DIDI-HUBERMAN, 2008, p.304), movimento pulsante, estabelecido pelas muitas relações que se multiplicam à medida de seu estabelecimento, provocando choques entre imagens que eclodem em constelações de sentidos e possibilidades, em saberes.

Imaginamos que tal movimento de pensamentos e sentidos; tais jogos de analogias, rupturas, desconstruções e reconstruções; tal trabalho de montagem movido pela coalescência do sensível e inteligível, pela reciprocidade de olhares entre aquele que observa e o observado, é o movimento mesmo da criação poética.

Diante de uma imagem, estaríamos diante de uma "porta aberta". Estaríamos diante da ambivalência da revelação e obscuridade. Estaríamos diante da potência de um jogo dialético, mantido em suspensão, de construções imprevisíveis e infinitas, de "movimentos em bifurcações", de dispersão de doutrinas (DIDI-HUBERMAN, 2008, p. 294). Diante de uma imagem, estaríamos diante das reentrâncias do entrelaçado de tempos heterogêneos carregados e encarregados de múltiplos discursos e percepções, atualizados no encontro com os nossos discursos e nossas percepções, com nossas histórias e memórias. Diante de uma imagem, estaríamos diante da potencialidade poética. Da experimentação do pensar, do sentir e do saber. Experimentação no sentido mesmo da relação afetiva, desejante, como lugar da coalescência do sensível e inteligível, do observador e observado, do sujeito e seu mundo.

A experimentação do saber eclodida desse encontro com a imagem, sob uma posição "epistemo-crítica", "epistemo-desejante" (DIDI-HUBERMAN, 2008, p. 227 317 ), coincide com a experimentação do trabalho poético ${ }^{9}$, entendido neste texto

9 O termo poético é aqui entendido como trabalho de criação e recriação estética. Um trabalho que implica o envolvimento e a consideração de processos sensíveis e inteligíveis; que implica na assunção, como constituintes desse processo de criação, daquilo que é aparente e inaparente; do que é previsto e imprevisto; do que é palpável e impalpável, comensurável e incomensurável. Trabalho que se mantém aberto aos desvios provocados pelo embate entre criador e criatura, 
como essencial ao trabalho da docência e, portanto, essencial aos processos elaborados como caminhos de formação para este ofício. O exercício de "leitura" de imagens e o da imaginação, intrínseco a ele, podem se tornar atos de resistência, contra um regime epistêmico que subsidia e determina a estruturação de um sistema educacional negligente, deliberadamente - aproveitando-se das ignorâncias - quanto aos vínculos entre os sujeitos e seus mundos, entre o sensível e o inteligível. Sistema este que impede com rigor metódico, por sua insistência e continuidade, o reconhecimento da importância do inaparente, da sutileza, dos entremeados de tempo, das imprevisibilidades, dos desvios, dos afetos, do corpo, do desejo, para os processos de construção de saberes. Sistema que impede o reconhecimento dos lugares de construção de saberes como lugares do possível, como lugares possíveis que, de forma paulatina, atua para o esmorecimento de nossa confiança sobre a potência do trabalho de "imaginar-se", imaginar-nos.

A imagem que introduz as elaborações contidas nesse texto nasceu de uma proposição poética de Thomaz Rosa, em uma das aulas da disciplina Didática Geral, realizada em 2012. O texto "Uma Didática da Invenção" de Manoel de Barros era uma de nossas referências. Foi proposto aos que participavam destas aulas, a exposição da "leitura" de uma das partes desse poema escolhido "para mobilizar conceitos e sentidos sobre a delicada relação entre didática, arte e educação"10. Ao responder a este exercício, Thomaz levou uma máquina de escrever e solicitou que cada um de nós escrevesse o que nos fosse suscitado no momento imediato do nosso encontro com aquele objeto. Essa imagem, filigranada por memórias e gestos cheios de delicadeza, os de Thomaz e os de cada um dos participantes desse ato, guarda um tanto de potencial sintético do que foi essa experiência, posteriormente, nomeada “(In)Versões Didáticas”. Os trabalhos originados por esta proposição foram expostos na Galeria do Instituto de Artes da UNESP por duas vezes. Uma em agosto de 2012,

produtor e produção, artesão e artesania, sem desconsiderar a condição de reciprocidade e intercâmbio contínuo desses papéis. Trabalho delicado que não pode prescindir do reconhecimento de uma articulação de saberes, e não saberes, elaborados coletivamente ao longo de uma multiplicidade de tempos e espaços.

10 Trecho do texto de apresentação da segunda exposição resultante deste trabalho, realizada durante o XXII CONFAEB 2012 -ARTE/EDUCAÇÃO: CORPOS EM TRÂNSITO. [acervo pessoal]. 
quando este espaço expositivo tornou-se também espaço para diálogos sobre arte e educação $^{11}$; a outra durante o XXII CONFAEB 2012 - ARTE/EDUCAÇÃO: CORPOS EM TRÂNSITO. Deixo meus agradecimentos a todos que compartilharam desta experiência, especialmente aos graduandos de Licenciatura em Artes Visuais que participaram destas aulas ${ }^{12}$. Essas pessoas com todas as suas delicadezas manifestas em suas elaborações poéticas, em suas imagens originadas no encontro da poesia de Manoel de Barros com suas reflexões sobre as relações entre arte e educação, criaram lugares abertos ao possível, experimentaram e nos fizeram experimentar exercícios de imaginação, motivados pelo encontro entre os repertórios diversos que constituem uma sala de aula. Trabalho de fricção e imiscuição entre algo aparentemente enrijecido e a possibilidade de sua recriação, devolvendo aos processos propostos como educacionais o seu caráter poético. Especificamente, esse trabalho, mantido pela "leitura" de imagens e, por isso, pelo exercício da imaginação, foi realizado no sentido de propiciar lugares possíveis à experimentação de poéticas para o trabalho didático. Lugares que promovessem o reconhecimento e preservação de parte essencial da arte, da educação e de suas relações, o seu potencial poético.

11 22/08 a 30/08 (Galeria do IA) - (IN) VERSÕES DIDÁTICAS - Exposição de trabalhos dos integrantes do IV BLAV a partir da leitura do poema Uma didática da Invenção de Manoel de Barros; 22/08 - 10:00 hs (Galeria do IA) - Conversa com Saint-Clair R. Nogueira Filho, educador e músico, estudante da licenciatura em Educação Musical do IA/UNESP: Música como produção de estudantes do Ensino Médio; 22/08 - 14:00 hs (Galeria do IA) - Conversa com Bia Nascimento, estudante da licenciatura em arte-teatro do IA/UNESP que apresenta seu TCC: Diálogos a procura da liberdade: possibilidades de uma prática anarquista de Educação; 24/08 - 19:00 hs (Teatro Reynúncio) - Conversa com o prof. Ms. Enio Tadeu Freitas, mestre em Artes pelo IA/UNESP e professor da Escola Municipal Campos Sales de Heliópolis: encarnações de palavras e imagens a partir do filme The Pillow Book (O Livro de Cabeceira) de Peter Greenway; 29/08 - 10:00 hs (Galeria do IA) - Conversas sobre estágio em ensino não formal - prof. Ms. Guilherme Nakashato e Profa. Ms. Camila Serino Lia, mestres em Artes pelo IA/UNESP; 29/08 - 14:00 hs (Galeria do IA) Conversas sobre história de vida e formação - profa. Ms. Camila Serino Lia e profa. Dra. Rejane Coutinho.

12 Adriano Vilela, Ana Druwe, Ana Luísa Chinatto Vassole, Bárbara Há Milanos, Barbara Messas, Bianca Selofite, Bruno Moreira, Carmen Cardoso, Damiana Vasconcellos de Carvalho, Daniele Desierrê, Daphine Juliana, Ed Peixoto, Felipe Morelatto, Gabriel Marcondes Egestos, Gabriel de Souza, Maira Coelho, Mariana Coyado, Naia De Oliveira Dib, Pedro Moreira, Ricardo Fialho, Sandra Mazzini Marcondes, Thomaz Rosa. 


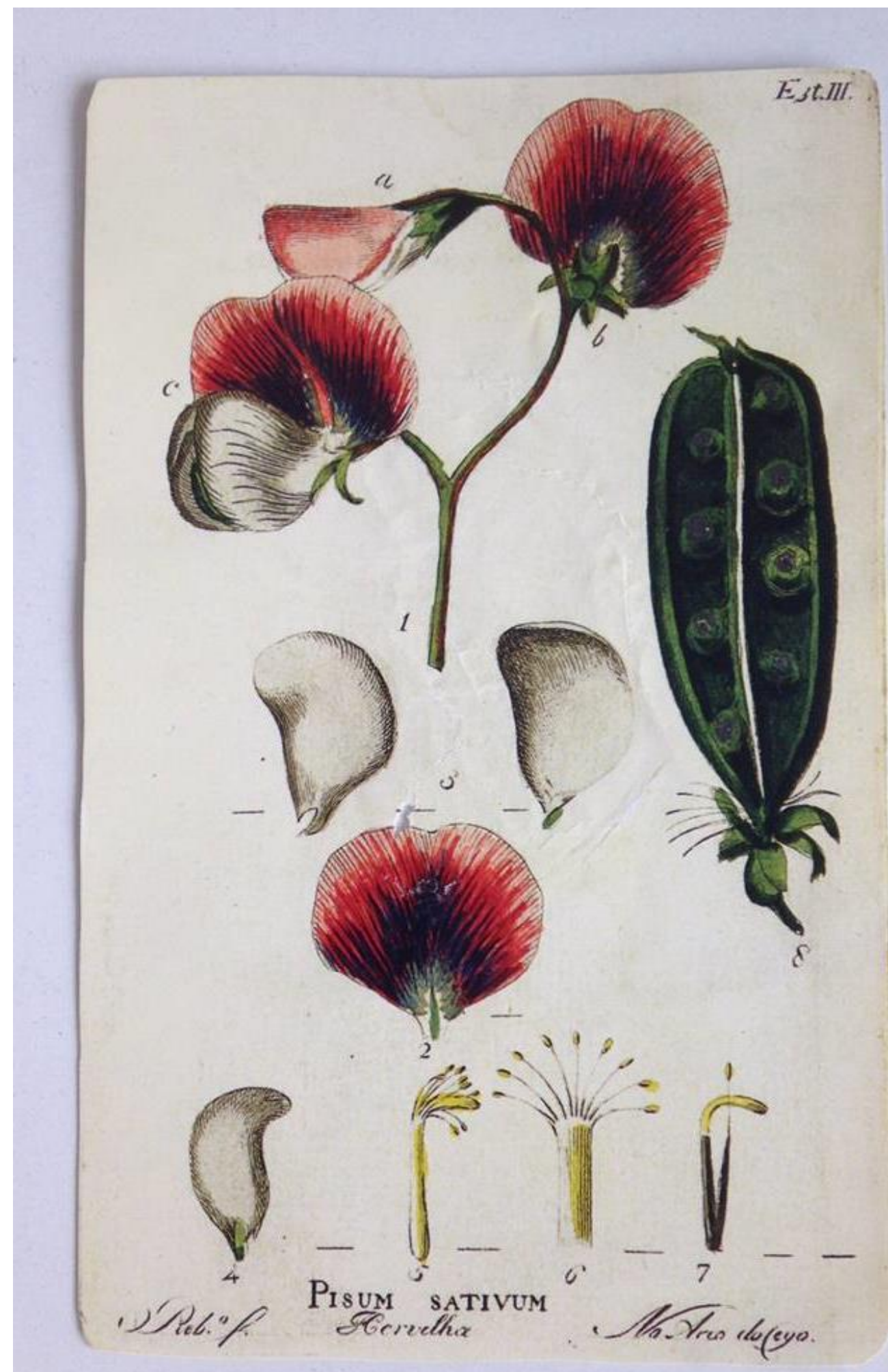

13 Detalhe do trabalho de Ed Peixoto realizado sobre a leitura do poema Uma Didática da Invenção de Manoel de Barros, 2012. 


\section{Referências}

BATAILLE, G. L'expérience intérieure. Éditions Gallimard. Paris, 1973.

BAUDELAIRE, C. Novas Notas Sobre Edgar Poe. In: LOURENÇO, J. F. (2006) A invenção da Modernidade (Sobre Arte, Literatura e Música). Relógio D’Água Editores. Lisboa, 2006, pp. 94-111.

BAUDELAIRE, C. A Rainha das Faculdades. In: Lourenço, J. F. A invenção da Modernidade (Sobre Arte, Literatura e Música). Relógio D’Água Editores. Lisboa, 2006, p. 157-161.

DIDI-HUBERMAN, G. Ante el Tiempo: historia del arte y anacronismo de las imágenes. Adriana Hidalgo editora. Buenos Aires, 2008a.

DIDI-HUBERMAN, G. Atlas ou a Gaia Ciência Inquieta. KKYM. Lisboa, 2013.

DIDI-HUBERMAN, G. Cuando las imágenes tocan lo real. Disponível em: <http://www.macba.cat/uploads/20080408/Georges_Didi_Huberman_Cuando_las_imagenes_tocan_I o_real.pdf>. Acesso: 29 mar. 2016.

DIDI-HUBERMAN, G. Cuando las imágenes toman posición. A. Machado Libros. Madrid, 2008b.

DIDI-HUBERMAN, G. Imagens Apesar de Tudo. KKYM. Lisboa, 2012.

DIDI-HUBERMAN, G. L'image ouverte: motifs de l'incarnation. Éditions Gallimard. Paris, 2007a.

DIDI-HUBERMAN, G. O que vemos, o que nos olha. Editora 34. São Paulo, 2005.

DIDI-HUBERMAN, G. Un conocimiento por el montaje In: Revista Minerva. Revista electrónica. Numero 5. Revista del Círculo de Bellas Artes. Disponível em: <http://www.circulobellasartes.com/fich_minerva_articulos/Un_conocimiento_por_el_montaje_\%2 84833\%29.pdf>. Acesso: 29 mar. 2016.

DUSSEL, I; ABRAMOWSKI, A.; IGARZÁBAL, B.; LAGUZZI, G. Aportes de la Imagen en la Formación Docente: Abordajes conceptuales y pedagógicos. In: Documento Pedagogias de la Imagen (2010). Instituto Nacional de Formación Docente. Proyecto Red de Centros de Actualización e Inovación Educativa (C.A.I.E). Disponível em: $<$ http://cedoc.infd.edu.ar/upload/24_2010_Documento_Pedagogias_de_la_Imagen_Ines_Dussel_y_otros_ver sion_preliminar.pdf>. Acesso: 29 mar. 2016.

LABORIE, A. T. Climatosofía de la formación artística. In: 1a․ Bienal de Educación Artística: Arte y Educación Geografía de um vínculo. Disponível em: $<$ http://educacion.mec.gub.uy/innovaportal/file/45270/1/libro bienal.pdf>. Acesso: 29 mar. 2016.

RANCIĖRE, J. O espectador emancipado. Orfeu Negro. Lisboa, 2010.

SARTRE, J-P. A imaginação. L\&PM. Porto Alegre, 2011.

\section{Rita Luciana Berti Bredariolli}

Realizou Pós-Doutorado no Program in Art and Art Education, Teachers College, Columbia University, sendo bolista CAPES do Programa de Estágio Pós-Doutoral no Exterior. Doutora e mestre em Artes pela Escola de Comunicações e Artes da Universidade de São Paulo, ECA-USP. Atualmente é professora do Instituto de Artes da Universidade Estadual Paulista "Julio de Mesquita Filho", IA UNESP. É uma das coordenadoras do GPIHMAE (Grupo de Estudos e Pesquisas sobre Imagem, História e Memória, Mediação, Arte e Educação). É autora dos livros 'Ao revés do pós: variações sobre temas de arte e educação' (Editora Unesp, 2013) e 'Das lembranças de Suzana Rodrigues: tópicos modernos de arte e educação'(Edufes, 2007).

E-mail: rluciana@uol.com.br

Currículo: http://buscatextual.cnpq.br/buscatextual/visualizacv.do?id=K4730992T9

Recebido em 20 de fevereiro de 2016 Aceito em 11 de abril de 2016 